\title{
Role of Plant Hormones on Vegetative Growth of Tomato (Lycopersicon esculentum Mill.)
}

\author{
Saurabh Tomar, Sanjive Kr. Singh, A.K. Dubey, Jagendra Pratap Singh* and Abhishek \\ Department of Horticulture, Chandra Shekhar Azad University of Agriculture and Technology \\ Kanpur 208002 (U.P.), India \\ *Corresponding author
}

\section{A B S T R A C T}

\begin{tabular}{|c|c|}
\hline & \multirow{4}{*}{$\begin{array}{l}\text { A field trial on the effect of different plant growth regulators viz., } \mathrm{GA}_{3}, \mathrm{NAA} \text { and } \\
2,4-\mathrm{D} \text { was conducted on tomato } \mathrm{cv} \text {. Azad T- } 6 \text { during the rabi season of } 2014-15 \text {. } \\
\text { The different concentration of } \mathrm{GA}_{3}(10,20 \text { and } 30 \mathrm{ppm}) \text {, NAA }(20,25 \text { and } 30 \\
\text { ppm) and } 2,4-\mathrm{D}(5,10 \text { and } 15 \mathrm{ppm}) \text { were sprayed on the crop to study the } \\
\text { vegetative growth behaviour attributes of tomato. It was found that there was a } \\
\text { linear increase in growth parameters like plant height and number of branches per } \\
\text { plant with increasing level of } \mathrm{GA}_{3} \text { and NAA. The maximum plant height was } \\
\text { recorded as } 99.03 \mathrm{~cm} \text { and } 85.47 \mathrm{~cm} \text { with the application of GA } 330 \text { ppm and } \\
\text { NAA @ } 30 \text { ppm, respectively at the time of harvesting Similarly, the other growth } \\
\text { attributes were also affected significantly with increasing concentrations of } \mathrm{GA}_{3} \text {, } \\
\text { NAA and 2,4-D. }\end{array}$} \\
\hline & \\
\hline Arti & \\
\hline & \\
\hline
\end{tabular}

\section{Introduction}

Vegetable is the most important component of a balanced human diet and protective act as a protective food. Among all the vegetables, tomato (Lycopersicon esculentum Mill.) is one of the most popular and widely grown vegetables in the world, ranking second after potato and it is grown under wide range of climatic conditions. Presently, a large number of growth regulators are available in the market but basically they are of two types i.e. growth promoters and growth inhibitors or retardants. Among growth promoters, Gibberellic Acid $\left(\mathrm{GA}_{3}\right)$ Naphthalene Acetic Acid (NAA) and 2, 4-Dichlorophenoxy Acetic Acid (2, 4-D) play an important role to improve the plant growth and yield of vegetable crops. $\mathrm{GA}_{3}$ is one of the important growth stimulating substances which, promote cell elongation and cell division thus, help in the growth and development of many plants. NAA affects the physiological processes, hastens maturity and improving the quality of fruits. 2,4-D significantly reduce the plant height and inter nodal length, days to flowering, acidity and number of seeds per fruit, but it increase fruit set, number of fruits, T.S.S., number of secondary roots and yield. Application of plant growth regulators for improving the yield and quality of many vegetable crops has been emphasized by several workers (Pundir and Yadav, 2001; Bhosle et al., 2002 and Meena, 2008). 
However, the improvement in the yield and quality of the crops mainly depends on the concentration of plant growth regulator and time of application (Singh, 1995). Therefore, the present investigation was carried out to study the effect of $\mathrm{GA}_{3}$, NAA and 2, 4-D on vegetative growth of tomato cv. Azad T-6.

\section{Materials and Methods}

The present experiment was conducted at the Horticulture Garden of Department of Horticulture, Chandra Shekhar Azad University of Agriculture and Technology Kanpur during rabi reason of 2014-15. The soil of the experimental site was sandy loam texture and slightly alkaline reaction. The experiment was laid out in Randomized Block Design (RBD) with three replications. The treatments comprised of three levels each of Gibberellic Acid $\left(\mathrm{GA}_{3}\right)$ i.e. (10, 20 and 30 ppm), Naphthalene Acetic Acid (NAA) 20, 25 and $30 \mathrm{ppm}$ and 2, 4-D (5, 10 and $15 \mathrm{ppm})$ along with a control. Thirty days old seedling of tomato (cv. Azad T-6) was transplanted on $1^{\text {st }}$ November, 2014 at a distance of $60 \mathrm{~cm} \times$ $40 \mathrm{~cm}$ in $1.8 \times 1.2 \mathrm{~m}$ plots. Nitrogen was applied @ $100 \mathrm{~kg} / \mathrm{ha}$ in three split doses. Half dose of nitrogen was applied as basal and rest half in the two equal split doses at 30 and 50 days after transplanting. Potassium and phosphorus were applied @ 50 kg/ha each as basal through murate of potash and Single super phosphate, respectively. For the application of growth regulators, first of all a stock solution of $1000 \mathrm{ppm}$ of $\mathrm{GA}_{3}$, NAA and 2, 4-D was prepared. Then working solutions of $10,20,30 \mathrm{ppm}$ of $\mathrm{GA}_{3}, 20,25,30 \mathrm{ppm}$ of NAA and 5, 10, 15 ppm of 2, 4-D were prepared by diluting the stock solutions with distilled water. The spraying of these solutions of $\mathrm{GA}_{3}$, NAA and 2, 4,-D was done as per the treatments at different time intervals. The first spray was done after 15 days of transplanting and subsequently two sprays were done at 15 days intervals. The crop was raised following standard agronomic practices. The data on growth parameters like plant height, number of primary and secondary branches per plant, number flowers per plant, number of fruits per plant, fruit length, fruit weight and diameter of fruit were recorded at different growth stages by selecting five plants randomly in each, experimental plot and the data were analyzed as per standard analytical procedures.

\section{Results and Discussion}

The data on growth parameters i.e. plant height, number of primary and secondary branches per plant, number of flowers and fruits per plant, fruit length, fruit diameter and fruit weight as influenced by $\mathrm{GA}_{3}$, NAA and 2, 4-D application at various growth stages are presented in figures 1,2 and 3 . It is evident from the data that the plant height and number of primary and secondary branches per plant, number of fruits per plant, fruit length and fruit diameter increased significantly with the increasing level of $\mathrm{GA}_{3}$, NAA and 2, 4-D.

The maximum plant height was recorded as $99.03 \mathrm{~cm}, 85.47 \mathrm{~cm}$ and $69.1 \mathrm{~cm}$ with the spray of $\mathrm{GA}_{3} @ 30$ ppm, NAA @ 30 ppm and 2, 4-D@5 ppm, receptively at the time of harvesting. Similar trend was also noticed with the number of primary and secondary branches per plant. This might be due to rapid increase in cell division and cell elongation in the meristematic region. These results are in conformity with those of Gupta and Gupta (2000) and Rai et al., (2006). The results presented in table 1 and 2 clearly show that fruiting and vegetative growth parameters such as percent of fruit set, number of fruits per plant, average fruit weight, length of fruit and fruit diameter increased significantly with the application of $\mathrm{GA}_{3}$, NAA and 2, 4-D. It is due to the fact that application of $\mathrm{GA}_{3}$, NAA and 2, 4-D check the flowers and fruit drop and ultimately increase the percent of fruit set. These findings are in accordance with the 
work reported by Meena, (2008).

Table.1 Effect of different concentrations of $\mathrm{GA}_{3}$, NAA and 2, 4-D on plant height number of primary and secondary branches, number of flowers per plant

\begin{tabular}{|c|c|c|c|c|}
\hline Treatment & $\begin{array}{c}\text { Plant height } \\
\text { (cm) }\end{array}$ & $\begin{array}{c}\text { No. of primary } \\
\text { branches }\end{array}$ & $\begin{array}{c}\text { No. of secondary } \\
\text { branches }\end{array}$ & $\begin{array}{c}\text { No. of } \\
\text { flowers/plant }\end{array}$ \\
\hline Control & 68.36 & 8.70 & 8.35 & 40.73 \\
\hline $\mathrm{GA}_{3} 10 \mathrm{ppm}$ & 78.56 & 12.99 & 12.45 & 44.96 \\
\hline $\mathrm{GA}_{3} 20 \mathrm{ppm}$ & 95.53 & 13.27 & 12.75 & 45.73 \\
\hline $\mathrm{GA}_{3} 30 \mathrm{ppm}$ & 99.03 & 13.39 & 12.85 & 47.71 \\
\hline NAA 20 ppm & 78.10 & 10.05 & 9.65 & 46.06 \\
\hline NAA 25 ppm & 84.35 & 10.95 & 10.50 & 45.63 \\
\hline NAA 30 ppm & 85.47 & 11.67 & 11.15 & 45.60 \\
\hline 2, 4- D 5 ppm & 69.10 & 10.26 & 9.87 & 48.80 \\
\hline 2, 4- D 10 ppm & 64.86 & 9.27 & 9.15 & 41.65 \\
\hline 2, 4- D 15 ppm & 60.55 & 9.12 & 8.78 & 41.65 \\
\hline C D (0.05) & 4.52 & 1.56 & 1.34 & 2.63 \\
\hline
\end{tabular}

Table.2 Effect of different concentrations of $\mathrm{GA}_{3}$, NAA and 2, 4-D on number of fruits per plant, fruit length, fruit weight and fruit diameter

\begin{tabular}{|c|c|c|c|c|}
\hline Treatment & $\begin{array}{c}\text { Number of } \\
\text { fruits per plant }\end{array}$ & $\begin{array}{c}\text { Fruit length } \\
(\mathbf{c m})\end{array}$ & $\begin{array}{c}\text { Fruit weight } \\
(\mathbf{g})\end{array}$ & $\begin{array}{c}\text { Fruit } \\
\text { diameter(cm) }\end{array}$ \\
\hline Control & 22.06 & 3.78 & 44.16 & 4.45 \\
\hline $\mathrm{GA}_{3} 10 \mathrm{ppm}$ & 42.15 & 4.10 & 112.10 & 9.59 \\
\hline $\mathrm{GA}_{3} 20 \mathrm{ppm}$ & 46.36 & 4.43 & 121.68 & 11.56 \\
\hline $\mathrm{GA}_{3} 30 \mathrm{ppm}$ & 47.06 & 5.16 & 134.85 & 12.45 \\
\hline $\mathrm{NAA} 20 \mathrm{ppm}$ & 36.16 & 3.76 & 81.23 & 6.80 \\
\hline $\mathrm{NAA} 25 \mathrm{ppm}$ & 39.43 & 3.43 & 83.08 & 7.55 \\
\hline $\mathrm{NAA} 30 \mathrm{ppm}$ & 41.45 & 4.14 & 86.26 & 7.90 \\
\hline 2, 4- D 5 ppm & 30.93 & 3.80 & 65.36 & 5.49 \\
\hline 2, 4- D 10 ppm & 24.80 & 4.05 & 65.56 & 5.94 \\
\hline 2, 4- D 15 ppm & 23.00 & 3.44 & 69.43 & 6.20 \\
\hline C D (0.05) & 2.98 & 0.51 & 6.46 & 2.35 \\
\hline
\end{tabular}

Fig.1 Effect of different concentrations of $\mathrm{GA}_{3}$, NAA and 2, 4-D on plant height per plant

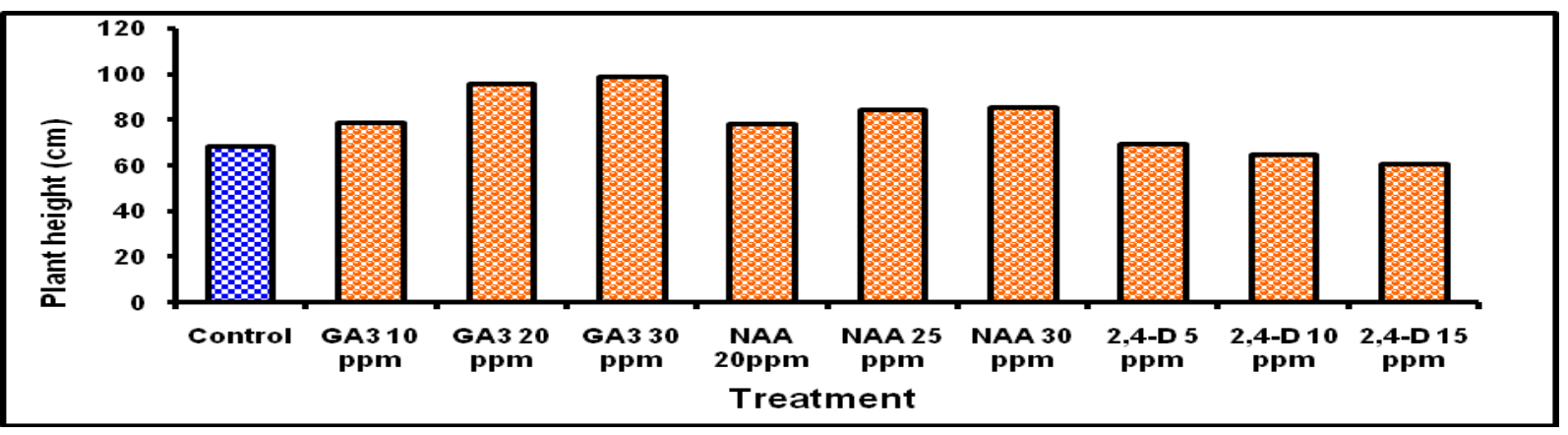


Fig.2 Effect of different concentration of $\mathrm{GA}_{3}$, NAA and 2, 4-D on

Number of primary branches per plant

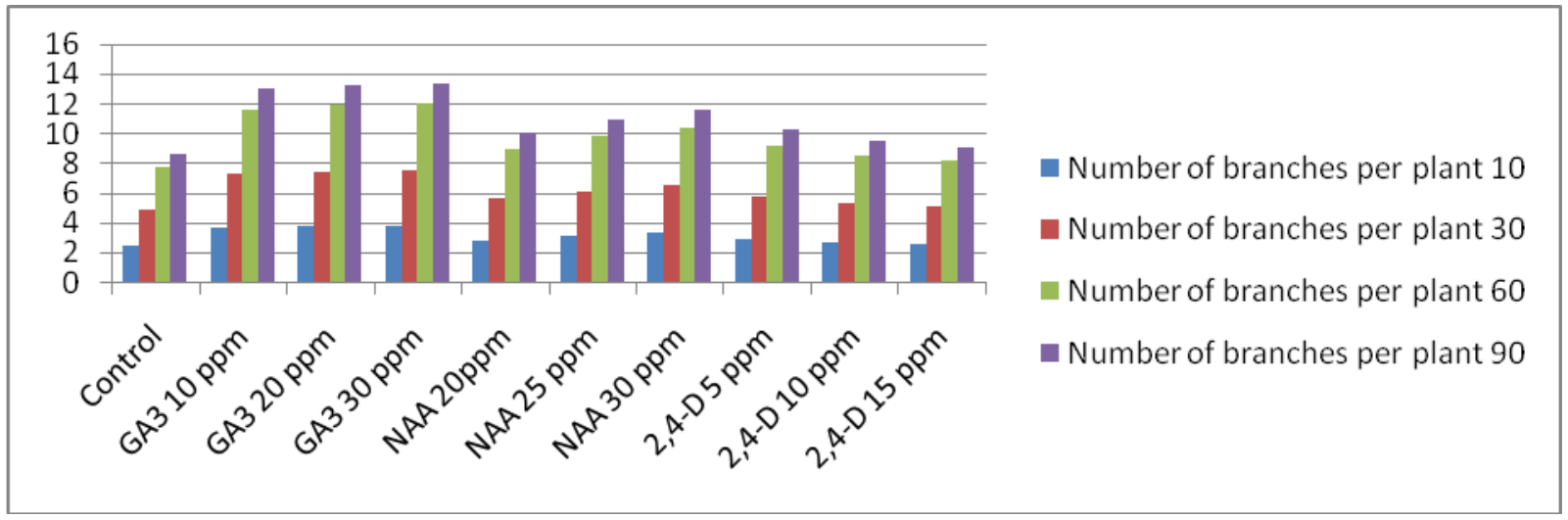

Fig.3 Effect of different concentration of $\mathrm{GA}_{3}$, NAA and 2, 4-D on

Number of secondary branches per plant

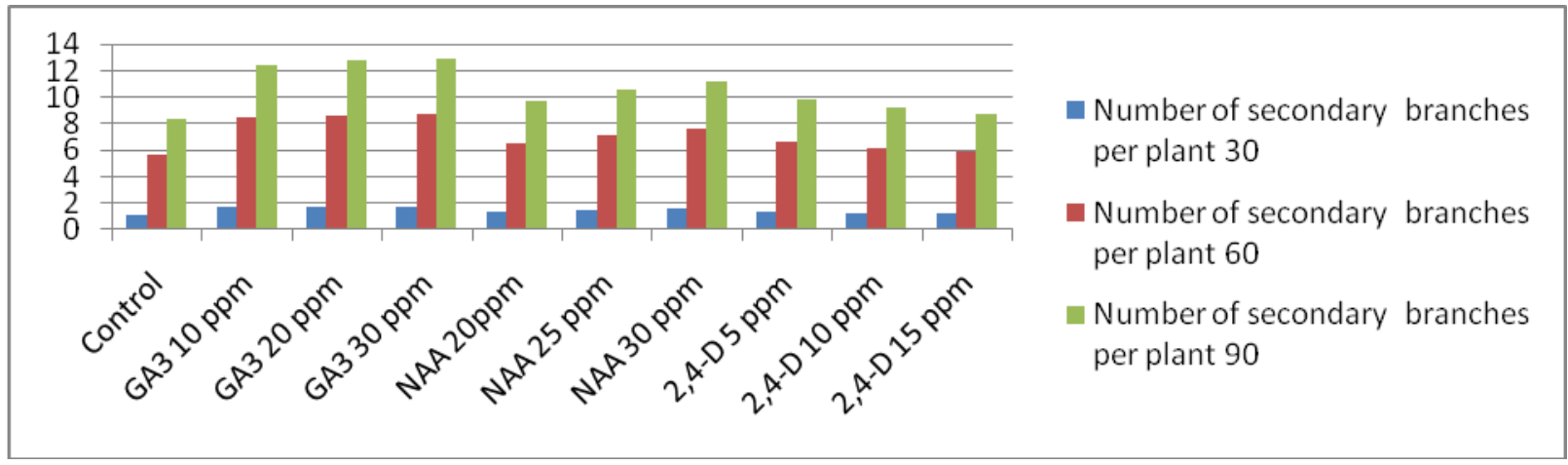

Application of $\mathrm{GA}_{3}$ and NAA significantly increased the number of fruits per plant, the increasing number of fruits per plant by $\mathrm{GA}_{3}$ and NAA treatment might be due to rapid and better nutrient translocation from roots to apical parts of the plant. These results are in accordance with those reported by Singh et al., (2001) and Bhosle et al., (2002). The size and weight of fruit is also an important aspect as these characters are useful for yield determination and consumer's acceptability. The average fruit weight, length of fruit and width of fruit were significantly increased with the application of $\mathrm{GA}_{3} \mathrm{NAA}$ and 2, 4-D and the maximum values were recorded at 30 ppm of $\mathrm{GA}_{3}, 30 \mathrm{ppm}$ of NAA and $5 \mathrm{ppm}$ of 2,4-D. This may be attributed to the increased supply of photosynthetic materials and its efficient mobilization in plant giving rise to increased stimulation of fruit growth ultimately resulting in increased fruit weight, fruit length and fruit diameter Bhosle et al., (2002) and Pundir and Yadav (2001).

From these results, it may be inferred that the application of $\mathrm{GA}_{3} @ 30$ ppm, NAA @ 30 ppm and 2, 4-D @ 5 ppm may be adopted to enhance the vegetative growth of plant and productivity of tomato.

\section{References}

Bhosle, A.B., Khorbhade, S.B., Sanap, P.B. and Gorad, M.J. 2002. Effect of plant hormones on growth and yield of summer tomato (Lycopersicon 
esculentum Mill.). Orissa Journal of Horticulture. 30 (2): 63-65.

Meena, R. S., 2008. Effect of $\mathrm{GA}_{3}$ and NAA on growth, yield and quality of tomato (Lycopersicon esculentum Mill.) Current Agriculture. 32 (1\&2): 83-86.

Pundir, J. P. S., Yadav, P. K. 2001. Effect of $\mathrm{GA}_{3}$ and NAA on growth, yield and quality of tomato. Current Agriculture. 25 (1\&2): 137-138.

Rai, N., Yadav, D. S., Patel, K. K., Yadav, R. K., Asati, B. S. and Chaubey, T. 2006. Effect of plant growth regulators on growth, yield and quality of tomato (Lycopersicon esculentum Mill. Wettsd.) Vegetable Science. 33 (2): 180-182.

Singh, S.P., 1995. Response of tomato (Lycopersicon esculentum Mill.) to plant growth substances. Advances in Horticulture and forestry 10 (2): 29-31.

Singh, B.K., Kumar, V, Singh, A.K and Ravi, V.K. 2001. Role of NAA on growth, yield and quality of tomato (Lycopersicon esculentum Mill.) Environ. Eco.27 (3):1091-1093.

\section{How to cite this article:}

Saurabh Tomar, Sanjive Kr. Singh, A.K. Dubey, Jagendra Pratap Singh and Abhishek. 2017. Role of Plant Hormones on Vegetative Growth of Tomato (Lycopersicon esculentum Mill.). Int.J.Curr.Microbiol.App.Sci. 6(9): 3319-3323. doi: https://doi.org/10.20546/ijcmas.2017.609.410 